WOJCIECH KOCJAN*

\section{Smart city Dubai}

\section{Smart city Dubai}

Streszczenie

Artykuł analizuje nowoczesne miasto DUBAJ w kontekście idei SMART CITY jako przykład wprowadzenia w praktyce modelowej idei zón noważo

Dubaj to wspollow szłości. Miejsce naprawde wyjatkowe, postepowe, kosmopolityczne, otwarte ale przede wszystkim wyprzedzające nasze czasy. To właśnie miasto przejęo pierwszeństwo spośród wszystkich aglomeracii światowych metropolii jako najbardzie innowacyjne i postępowe.
Obecnie najmodniejsze słowo SMART CITY - znak rozpoznawczy zrównoważonego rozwoju tkanki miejskiej, to też słowo -

Obecnie najmodniejsze slowo SMART CITY - znak rozpoznawczy zrównoważonego rozwoju tkanki miejskiej, to też słowo Dobrym przykładem tej idei jest SMART CITY DUBAI.

\section{Abstract}

The article analyses the modern city of Dubai in the context of the assumptions of the idea of the SMART CITY, as an example of introducing a model idea of the sustainable development of a city in practice.

Dubai is a modern agglomeration that is excellently managed and employs available technological novelties to the greates possible extent. It is a relatively new city - that has been built in a desert, in greatly unfavourable conditions - one that aspires to be a city of the future. Dubai is a progressive, cosmopolitan, open city, but it is mainly ahead of our times through being the most innovative and advanced.

The current term SMART CITY - the hallmark of the sustainable development of urban tissue - is a key element that identifies progress in the modern world. SMART CITY DUBAI appears to be an example that perfectly illustrates the idea of the intelligent city.

A good example of this idea is SMART CITY DUBAI.

Stowa kluczowe: Dubaj, smart city, zrównoważony rozwój, smart building

Keywords: Dubai, smart city, sustainable development, smart building

\section{Wstęp}

Dubaj miasto przyszłości, niezwykłe, wyjątkowe, postępowe, kosmopolityczne, otwarte...

Można by wymieniać wiele przymiotników, jednak najtrafniejszym określeniem jest innowacja. To miasto przejęło pierwszeństwo spośród wszystkich aglomeracji światowych metropolii jako najbardziej innowacyjne i postępowe.

Obecnie najmodniejsze słowo - znak rozpoznawczy zrównoważonego rozwoju tkanki miejskiej to SMART CITY - słowo klucz, znak rozpoznawczy postepu we współczesnym świecie. Tadeusz Zipser - Rektor i profesor Politechniki Wrocławskiej, wybitny urbanista i naukowiec, prekursor planowania przestrzennego prowadził badania nad ogromnym zaludnieniem miast i mówił znaczące słowa:

„Kryzys przychodzi w pantoflach. Po cichu, nie słychać go jak się zbliża, a czujemy go dopiero jak jest. Co 1 sekundę przybywa 2 mieszkańców miast. Po jednej godzinie przybędzie miasteczko liczące ok. 7200 mieszkańców. Oczywiście nie pojawi się "fizycznie" nowe miasto, ponieważ tych mieszkańców "upcha” się w istniejąca już strukturę. Jeśliby więc przeliczyć liczbę nowych mieszkańców na potrzebną do ich funkcjonowania powierzchnię, licząc ze średnią wielkością imponujący obszar wielkością równoważny powierzchn Francji czy Ukrainy. Nasuwa to pytanie o istote miasta i jego przyszłość ${ }^{\prime \prime}$

Obecnie problem przeludnienia dotyczy wielu miast, jednak właśnie Dubaj, jako nowoczesna metropolia, mierzy sie z napływem ludności nie tylko z samych Emiratów Arabskich czy z państw sasiednich, alo w znacznej mierze z calego czy z panstw sassiednich, ale $w$ znacznej mierze $z$ całego świata. Obecna ludnośc Dúry to niosźnka wszystkich ras, potkać spacerując ulich polityczne miasto na miarę przyszłości.

\section{Przeszłość patrzy w przyszłość}

To niezwykłe zjawisko, że takie pustynne miejsce nad Zatoka Perska jeszcze 80 lat temu zamieszkiwało około 10000 osób a teraz żyje tam ponad 2.8 miliona ludzi². Niezwykła jest trans formacja tego regionu świata, gdzie biedna beduińska osada zmieniona została na naszych oczach od lat 70 . minionego wieku w nowoczesne i dynamiczne miasto.

Bogactwo jakie zapewniły miastu połowy pereł sprawiło, że tał sie on szybkojednyz naiwiekszych portów w tym rejonie. Jal sie on szybko jednymz największych portów w tym rejonie. Jo do do pełnego rozkwitu Dubaju. Głowną rolę w rozwoju tego miasta odegrał szejk Rashid bin Saeed Al Maktoum. Jego przypadające na lata 1958-1990 rządy doprowadzily do tego, ze z małej wioski Dubaj stał się nowoczesną metropolia $z$ przemysłową infrastrukturą i komunikacją miejską na światowym poziomie.

Pieniądze zarobione na płynącej obficie ropie naftowej szejk poświęcił na przekształcenie Dubaju w ważny port tego regionu, a także międzynarodowe centrum handlu i usług finansowych. W swym wizjonerskim podejściu Rashid bin Saeed Al Maktoum wiedział że pokłady ropy nie są nieograniczon kiedyś sie wyczerpia Przez lata swych rzadów pracowat , by Dubaj pozostat śceztowa metropolia która przat na nawet, gdy pokłady ropy się wyczerpia $3^{3 \prime}$.

Dection O dowy, gdzie a rewlonych

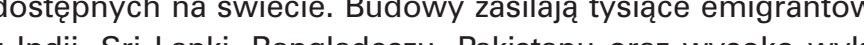
zalifikowanych inżynierów z Europy i Ameryki. Dubaj to już nie pojedyncze miasto, ale aglomeracja pełna nowatorskich rozwiązan komunikacyjnych, wspaniałej archi-
tektury i obecnie w pełni zasługującej do tytułu SMART CITY w pełnym tego słowa znaczeniu.

$w$ pełnym tego stowa znaczeniu. Mieszkańcy całych Emiratów w tym również Dubaju - jako autonomicznego państwa-miasta w ramach wspólnoty Zjednoczonych Emiratów Arabskich dostali niepodważalną szansę aby dzierżyć palmę pierwszeństwa wśród najnowocześniejszych miast świata w połączeniu nowych technologii z tkanka miejską w służbie mieszkańcom.

To wyzwanie na miarę przyszłości, aby miasto, liczące już ponad 2 miliony mieszkańców oraz odwiedzających je około 10 milionów turystów rocznie, scalić w żywy organizm, który zapewni komfort, przestrzen i jednoczesnie prywatnosc dla crammed into the existing structure. If we calculate the area needed for the functioning of these residents based on their number, assuming an average value of $200 \mathrm{~m}^{2} /$ person, then by the middle of the century we will be able to obtain an imposing area equal to that of France or Ukraine. This and its future"

The problem of overpopulation currently applies to many cities, however it is Dubai which as a modern metropolis, is facing the problem of the inflow of population not only from the United Arab Emirates themselves or from neighbouring countries, but from pretty much the entire world. The current population of Dubai is a mixture of al races, cultures, religions and skin colours from all over the world, which we can encounter when walking along the streets of this city - it is a truly
cosmopolitan city fit for the future.

\section{The past looks into the future}

The fact that such a desert-like place on the Persian Gulf was inhabited by around 10000 people only 80 years ago, with over 2,8 million people living there today is an extraordinary phenomenon ${ }^{2}$. The transformation of this region of the world, where a poor Bedouin settlement has been turning into traordinary.

The wealth that was provided to the city by pear hunting caused it to quickly become one of the largest ports in the region. However, it was the fully flourish. The main role in the leve Dubai to the city was played by sheikh Rashid bin Saeed A Maktoum His reign, which took place in the years 1958-1990, caused Dubai, once a small village, to urn into a modern metropolis with a world class industrial infrastructure and public transport. The money earned thanks to the rich flow of oil was spent by the Sheikh on transforming Duba into one of the region's important ports, as well as an international centre of trade and financial services. In his visionary approach, Rashid bin Saeed Al Maktoum knew that the oil deposits were not infinite and that one day they will be depleted. Over coming a has metropolis that will survive evewhen the oil deposits will run dry".3

Nowadays the entire agglomeration of Dubai is an unceasing construction site, where around $1 / 3$ of all of the world's construction cranes are employed. The construction staff is composed of thousands of migrants from India, Sri Lanka, Bangladesh and Pakistan, as well as highly qualified engineers from Europe and America.

Dubai is no longer an individual city, but an ag glomeration full of innovative circulation solutions and excellent architecture, in addition to being fully worthy of the title of a SMART CITY in the full
sense of the term. The residents of al th

The residents of all the Emirates, including those the commonwealth of the United Arab Emirates 
mieszkańców w zależności od indywidualnych potrzeb i oczekiwań.

To niezwykłe i śmiałe przedsięwzięcie, aby połączyć nowoczesność i rozmach zapewniając również dobre warunki do życia dla wszystkich, którzy chca obcować z prawdziwym miastem przyszłości.

To ta wizjonerska transformacja pozwala budować fenomen na skale świata, gdzie wszystko jest naj... najwieksza galeria handlowa na swiecie, najwyzszy budynek, najwię

Kierunkiem rozwoju Dubiu jest i decie n. wane EXPO 20205, gdzie światową wystawę będzie mogła niemalże dotknąć tego fenomenalnego miasta.

EXPO to wyzwanie logistyczne i test organizacyjny dla władz Dubaju. Miasto chce pokazać swoje możliwości na miarę przyszłości aby ludzie z całego świata poznali co to jest prawdziwy SMART DUBAl', aby dzięki tym rozwiązaniom mobilnym bezpiecznie i bezstresowo móc korzystać $z$ atrakcji i poruszać się bezproblemowo po całej okolicy.

\section{Smart - rozwiązanie przyszłości}

To właśnie wizja szejka JWS Mohammeda bin Rashida A Maktoum Wiceprezydenta i Premiera tak naprawdę "właściciela" ZEA' zainspirowała rząd do wprowadzenia 6 innowacyjnych programów tzw. inteligentnych usług miejskich obejmujących 6 kluczowych gałęzi życia społecznego:

inteligentna gospodarka

inteligentne życie

inteligentna mobilność

inteligentne zarządzani

inteligentne środowisko

inteligentni mieszkańcy

Wizja ta i wdrożenie wymienionych programów ma zaowocować tym, że całe Emiraty staną się najmądrzejszym i najszczęśliwszym miastem na ziemi.

Specjalna mobilna aplikacja prywatna zwana: The Dubai Personal Dashboard ${ }^{8}$ została uruchomiona przez Dubajską Ochronę Cywilna - Dubai Civil Defense (DCD) ${ }^{9}$ w 2015 roku $w$ celu umożliwienia mieszkańcom i turystom pełnego dow celu umożliwienia mieszkancom i turystom pełnego do-
stępu do wszystkich najważniejszych informacji dotyczących miasta, zachęcając do integracji mieszkańców i wymiany wzajemnej informacji w czasie rzeczywistym. To właśnie $\mathrm{m} /$ innymi przyczynia się do opinii, że Dubaj jest obecnie najbarinnymi przyczynia się do opinii, ze Dubaj
dziej inteligentnym miastem na świecie.

Pulpit zbiera i wyświetla dane ze źródeł publicznych i prywatPulpit zbiera i wyświetla dane ze źródeł publicznych i prywat-
nych oraz z mediów społecznościowych (Facebook - osobiste kanały, Tweeter - tweety rządowe). Aby umożliwić bezproblemowe logowanie, pulpit nawigacyjny wykorzystuje usługe MyID w Dubaju do pojedynczego logowania. Panel główny jest oparty na modułach, z których każdy przedstawia inna koncepcję. Moduły składają się z 3 typów:

Ogólne moduły informują użytkownika w czasie rzeczywistym o danych z pobliskich stacji straży pożarnej, biuletynu DCD, gazety Gulf News, tweetów rządowych, prognoz pogody. Przekazywany jest również dokładny czasy modlitwy na dany dzień;
- have been given an indisputable opportunity to bear the torch of leadership among the most advanced countries of the world in terms of combining new technologies with urban tissue in service

It is a challenge worthy of the future for a city that already has a population of over 2 million, with
around 10 million tourists visiting it each year, to b combined into a living organism that will provide comfort, space, and - at the same time - privacy to its residents depending on individual needs and expectations.

It is an extraordinary and bold undertaking to combine modernity and flair while also providing good living conditions for everybody who wants to experience a true city of the future. It is this visionary transformation that makes it possible to build a global phenomenon where everything is the greatest... the largest shopping mall in the world most luxurious hotel, tc ${ }^{4}$ The planned EXPO 2020 ,

205, where an enormous number of the visitors attending this global expocity, will indisputably be a direction of development for Dubai.

The EXPO is a logistical challenge and an organ sational test for the authorities of Dubai. The city wants to demonstrate its futuristic capabilities so that people from all over the world could learn the meaning of the true SMART DUBA ${ }^{6}$, so that they could safely and calmly partake of the attraction lems thanks to mobile solutions.

3. Smart - the solution of the future

It is the vision of HM Sheikh Mohammed bin Rashid Al Maktoum, the vice President and Prime Minister, and the actual "owner" of the United Arab Emirates ${ }^{7}$ that has inspired the government to introduce 6 innovative programmes of so-called smart municipal services covering 6 key sectors of public life:

smart economy

smart living

smart mobility

smart management

smart residents

This vision and the implementation of these programmes is meant to result in the Emirates becoming the smartest and happiest city on Earth.

A special private mobile application called The Dubai Personal Dashboard8 was prepared by the Dubai Civil Defence (DCD) 9 in 2015 in order to grant residents and tourists full access to key information about the city, encouraging the integration of residents and the sharing of mutual information in real time. It is this, among other things, that leads city in the world.

The Dashboard collects and shows data from public and private sources, as well as from social media (Facebook - personal channels, Twitter - gov-

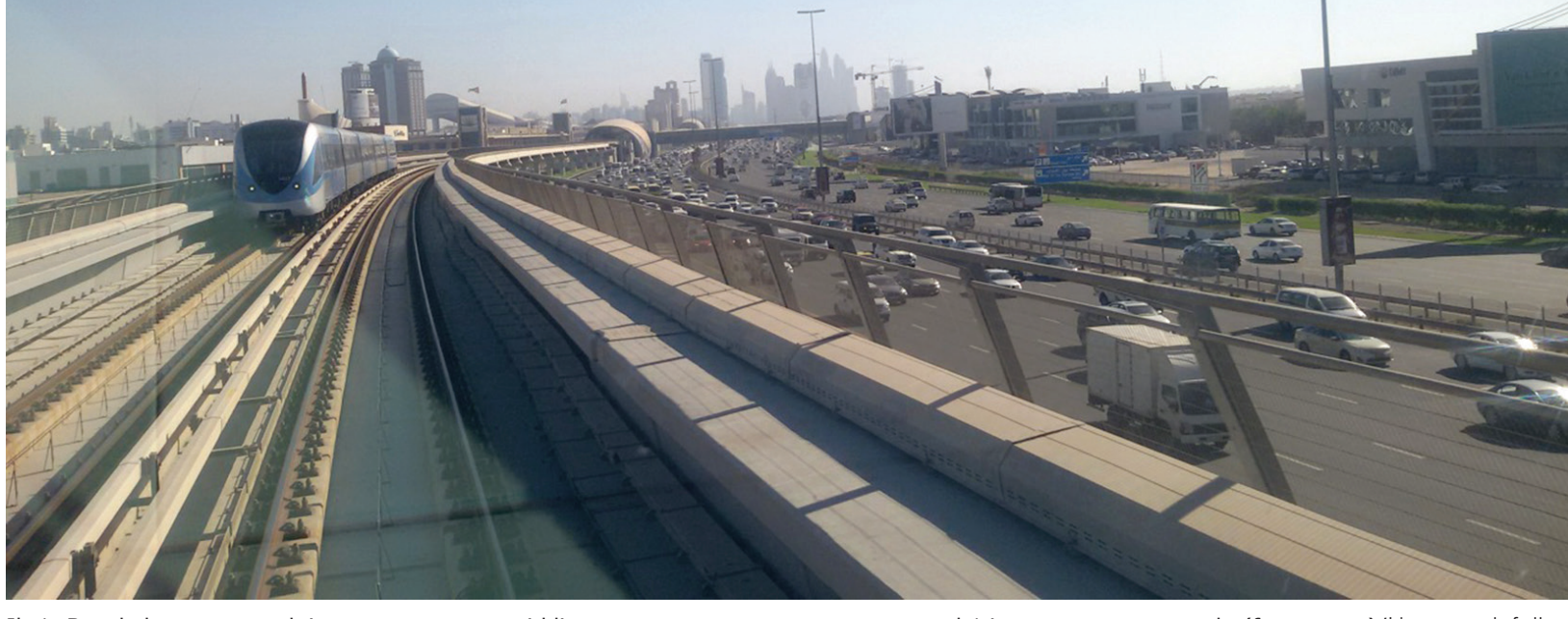

Il. 1. Bezobstugowe, w pethi zautomatyzowane i klimatyzowane metro usytuowane nad 14-paan
automated and air conditioned metro rail situated above a 14 -lane freeway. (phot. by the author)

\section{Key pillars of a smart city}

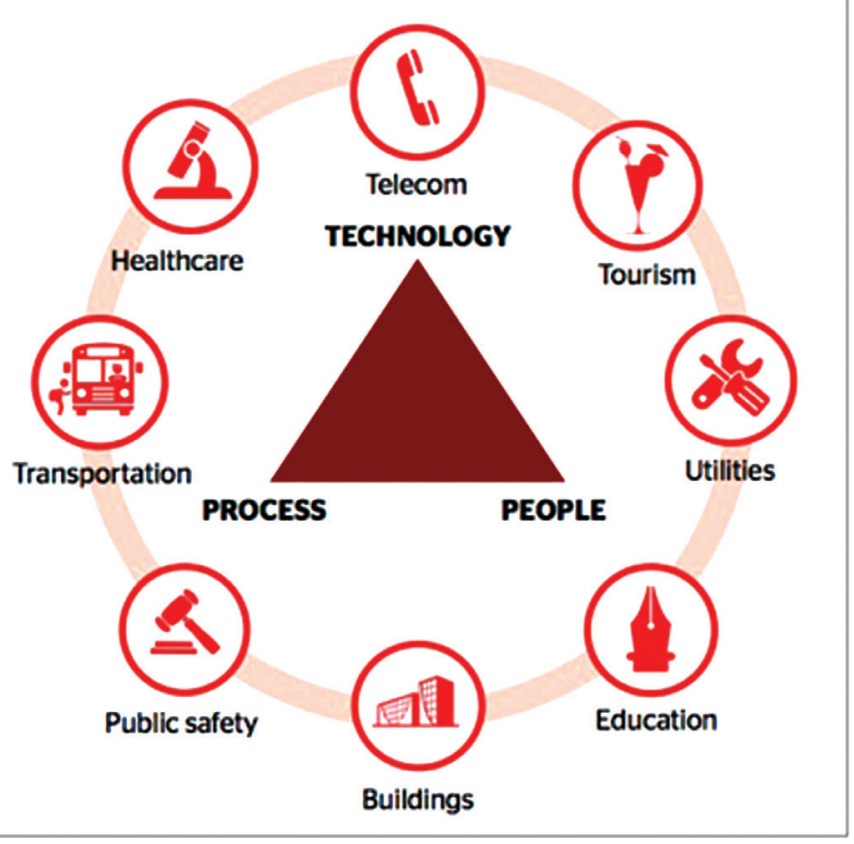

Source: KPMG

II. 2. Obraz głównych filarów założenia SMART CITY (foto: www.pacificcon-
trols.net/news-media/dubai-the-first-smart-city-in-the-region/Image of the main illars of the SMART CITY (photograph: www.pacificcontrols.net/new

Spersonalizowane moduły przesyłają dane związane $z$ konkretnym budynkiem, sa to tzw. moduły informacyine i alarmowe połączone np. z Facebookiem oraz monitoringiem budynku.

Moduły raportowania obsługują tzw. przycisk alarmowy w przypadku pożaru, koniecznej interwencji policji, pogotowia ratunkowego lub innego naruszenia bezpieczeństwa. Ta aplikacja zawiera możliwość tworzenia i wysyłania raport zawierającego szczegółowe informacje, zdjęcia lub wideo. ernment tweets). In order to enable easy logging he Dashboard uses the MylD service in Dubai for a des, There are three types of modules:

Teneral modules that inform the user about data from the local fire department, the DCD bullitin the Gulf News paper, government tweets and weather forecasts in real time. They also display the precise prayer times for a given day;

Personalised modules send data associated with a specific building, these are so-called information and alarm modules connected to, among other things, Facebook and a building's monitoring system.

Report modules feature a so-called alarm button in case of a fire, the necessity of a police or rescue service intervention or a different safety issue. This application provides the abilty to create and send report containing detailed information, image

The private dashboard is one of the many applicamation in Dubai. The mobile dashboard does not currently have a lot of information sources or com plicated urban analytics, which makes it a future direction of development, one that starts today ${ }^{10}$. Dubai has the ambition of a city that will become one of the most connected and sustainable "intelligent cities" in the world, open to future opportunities and developing new technologies.

There are currently around 1000 e-services operating in Dubai, offering a variety of services and

The UN has listed the United Arab Emirates as a regional leader in terms of e-services. The UN EGovernment Development Index 2016 published fairs lists the United Ar Economic and Social Afin the world, along with Estonia, in terms of providing e-services.

In 2008 Dubai implemented its world-first, multiple prize-winning national $24 \times 7$ life safety programme, 
Prywatny dashboard w Dubaju jest jedną z niewielu aplikacji, ktore obslugują i "obrabiaja spersonalizowane informacje. Panel mobilny nie ma obecnie wielu źródeł danych ani skomplikowanej analityki miejskiej, więc jest to kierunek rozwoju w przyszłość, która zaczyna się już dziś

Dubaj ma ambicje miasta które bẹdzie jednym z najbardziej połaczonych i zrównoważonych "inteligentnych miast" na świecie, otwarty na przyszłe możliwości i rozwijające sie nowe technologie. W catej aglomeracii Dubaju obecnie dzia ok. 1000 e-serwisów oferujac różnorodność usług i aplikaci11. ONZ plasue Zjednoczone Emiraty Arabske jako lidera w reONZ plasue Zjedn w ofe

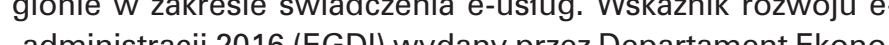
mii i Spraw Spo z mili i Spraw Spolecznych ONZ plasuje Zjednoczone Emiraty Arabskie, wraz z Estonią, na ósmym miejscu na świecie pod względem dostarczania e-usług.

Wz gradzany krajowy program bezpieczeństwa życia w cyklu 24x7 z wykorzystaniem najnowocześniejszej technologii M2M. Zaprojektowany i wdrożony przez Pacific Controls, krajowy oddzial dla $D C D$, program ten stanowi punkt odniesienia w sektor publiczno-prywatnym dla inicjatyw partnerskich w ZEA ${ }^{12}$.

Właśnie ta technologia M2M zapewnia obecnie bezpieczeństwo całego sektora prywatnego i rządowego w Dubaju w systemie 24×7×365 za pośrednictwem zintegrowanej centrali DCD.

Obecnie DCD jest jakby przedłużeniem osobistej aplikacji mobilnej (Personal Dashboard), który integruje skalę osobista mieszkańca ze skalą calego miasta (il. 3).

Prawdziwe zarządzanie systemem SMART CITY podsumowal dyrektor Obrony Cywilnej Dubaju major-generał Rashid Thani Al Matroushi:

„Pulpit nawigacyjny dodał więcej mocy do operacji DCD i zwiększył możliwości organizacji do analizowania danych dla lepszego podejmowania decyzii i wydajności organizacyinej nie tylko usprawnił wewnetrzną komunikacje w odniesieniu do monitorowania straży pożarneji zasobów alo także pokaza nasze zaangżowani dla mieszkańców, Każdy zokazal budynku w Dubaiu posiada teraz indywiduan tablice buzzzioza budynku, kóra wyświetla stan bezpieczeństice i higieny budynku, co równiez umożliwia innym depantsma iniginy budy buck rán

Dubaj jest obecnie pierwszym takim miastem w rejonie Bliskiego Wschodu, które posiada zintegrowany system spina-

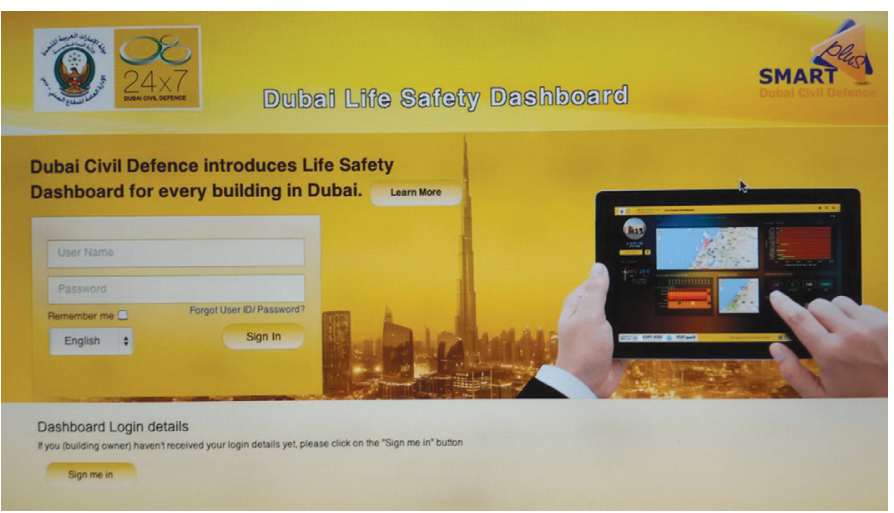

which uses M2M technology. Designed and developed by Pacific Controls, the national branch of DCD, the program constiutses a reference point for partnering initiatives in the public-private sector in the UAE

It is this M2M technology that currently provides security to the entire private and government sec-
tor in Dubai using the $24 \times 7 \times 365$ direct alarm system that utilises an integrated DCD command and control centre. DCD is currently a sort of an extension of the Personal Dashboard, which integrates the personal scale of a resident with the scale of the entire city (III. 3).

True governance of a city using a SMART CITY system was summed up by the Dubai Civil Defence director, major-general Rashid Thani Al Matroushi: The dashboard added more power to DCD's operations and enhanced the organisation's capabilities to analyse data for better decision-making and orinternal communication with regards to monitoring of the fire station and resources, but also demonstrated our commitment towards the residents. Every building owner in Dubai is now provided with an individual building dashboard that displays the health and safety status of the building, which also enables other government departments to facilitate innovative services to building owners and occupants".13

Dubai is currently the first city in the Middle East to have a system that connects all buildings that are simultaneously monitored. The system makes preventing fires, break-ins and mugging.

It is an immensely innovative undertaking, one the has been very costly initially, but one that will prove to be indispensable in the future.

\section{The next step}

Another greatly interesting and innovative project in the sphere of SMART DUBAl is the modern district called DUBAI SILICONE OASIS (DSO) ${ }^{14}$. It is a fully self-sufficient district functioning as an independent, integrated ecosystem, which is meant to be a place of informed choice for people who wan a transparent and safe environment. The district, want to live and work in a fully integrated, sustainable and happy community.

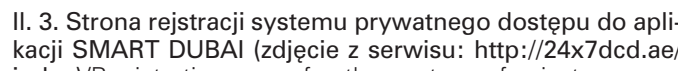
index)/Registration page for the system of private access
to the SMART DUSAl application limage obtained from the
Il. 4. Typowa stacija nowoczesnego metra (fot. autora)//Typical modern metro
rail station (phot. by the author)

jacy wszystkie budynki, które jednocześnie są monitorowane. System pozwala wykryć natychmiast jakiekolwiek zagrożenie bezpieczenstwa, zapobiega pożarom, włamaniom, rozbojom. Jest to niezwykle innowacyjne przedsięwzięcie, oczywiście bardzo kosztowne na etapie początkowym, ale jakże niezbędne w przyszłości.

\section{Następny krok}

Bardzo ciekawy i nowatorski projekt w obszarze SMART DU BAI to nowoczesna dzielnica DUBAI SILICONE OASIS (DSO) ${ }^{14}$ $W$ pełni samowystarczalna dzielnica jako niezależny zintegrowany ekosystem, który ma być miejscem świadomego wyboru dla ludzi, którzy pragną przejrzystego i bezpiecznego środowiska. Projektowana dzielnica zachęca osoby pragnące zamieszkać i pracowac w pełni zintegrowanej, zrownoważonej i szczęśliwej społeczności.

Jak informują nas założyciele SILICONE OASIS:

DSO szczyci sie tym, że jest jedynym przełomowym parkiem technologicznym, który jest w stanie zapewnic przedsiebiorcom biznesowym, lokalnym i zagranicznym, lo ka crock dla firm, które chca sie rozwinać i ostatecznie przeksztoze

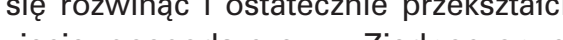
Emiratach Arabskich"15.

作 fort i wygodę mieszkania, oferuje mieszkańcom i odwiedzającym szeroki wachlarz wyjątkowych technologii, urządzeń $i$ usług których nie można doświadczyć w żadnym miejscu na świecie. W rzeczywistości DSO wdrożyła plany dotyczące rozwoju programu SMART CITY. Program modernizacji ma na celu zachęcenie lokalnej społeczności do pełnego korzystania z „inteligentnej technologii" w codziennym życiu.

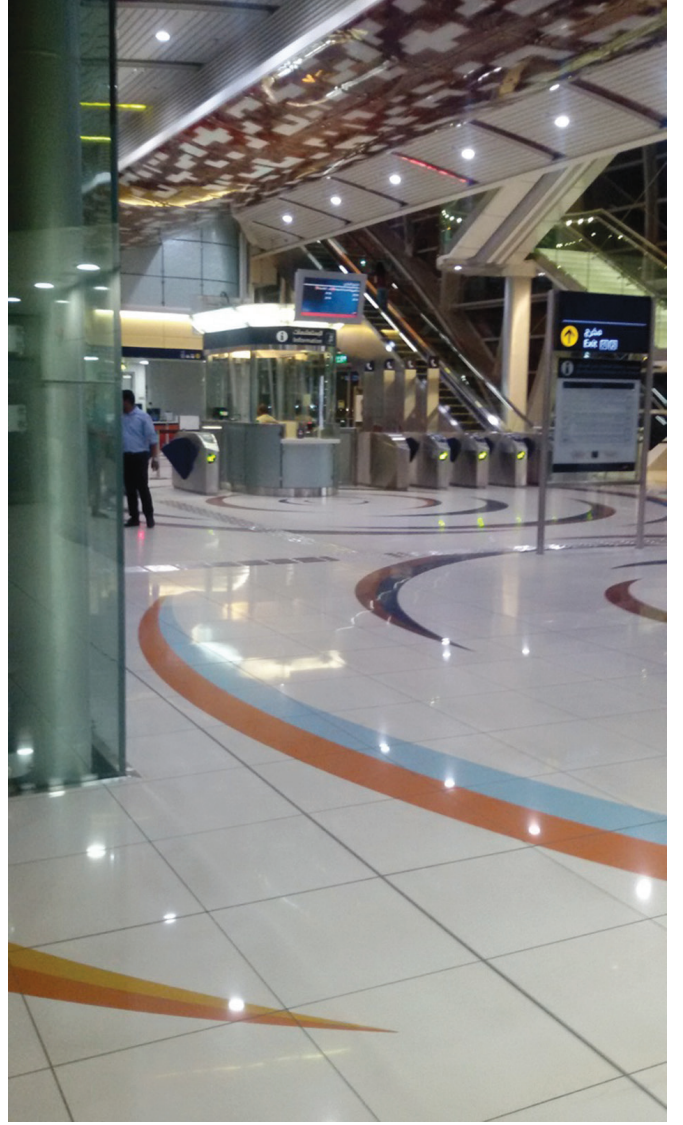

As the founders of SILICONE OASIS inform us that the DSO prides itself in being the only groundviding corporate, local and foreign entrepreneurs with a perfect platform to start a business. Its advanced infrastructure and facilities form a perfect foundation for companies that want to develop and transform into a successful business enterprise in the United Arab Emirates 15.

DSO, thanks to its exceptional conveniences in providing comfort and ease of living, offers residents and visitors a wide range of exceptiona technologies, devices and services which canno be experienced in any other place in the world. I develop $n$ of the SMART CITY programm The modernisation programme is meant to encourage the local community to fully embrace "smart technology" in everyday life.

Dubai has adopted its own unique approach to the smart city. This aspiration is based on three pillars: communication (technology), integration (process) and personal cooperation (ill. 2). This integrated approach will bear fruit and help to achieve the goal that is the transformation into a truly global smart city. 9

From smart cars to public Wi-Fi hotspots and smart localisation applications - these are jus the boundaries of technolis and pave the way to a smart future. ${ }^{16}$

Dubai can sometimes be a difficult city to navigate because some districts do not have a traditiona street address system. A highly advanced system has recently been introduced - called Makani Dubai ${ }^{17}$. Every building in Dubai has a unique, dedicated number that is displayed in a visible spot on 


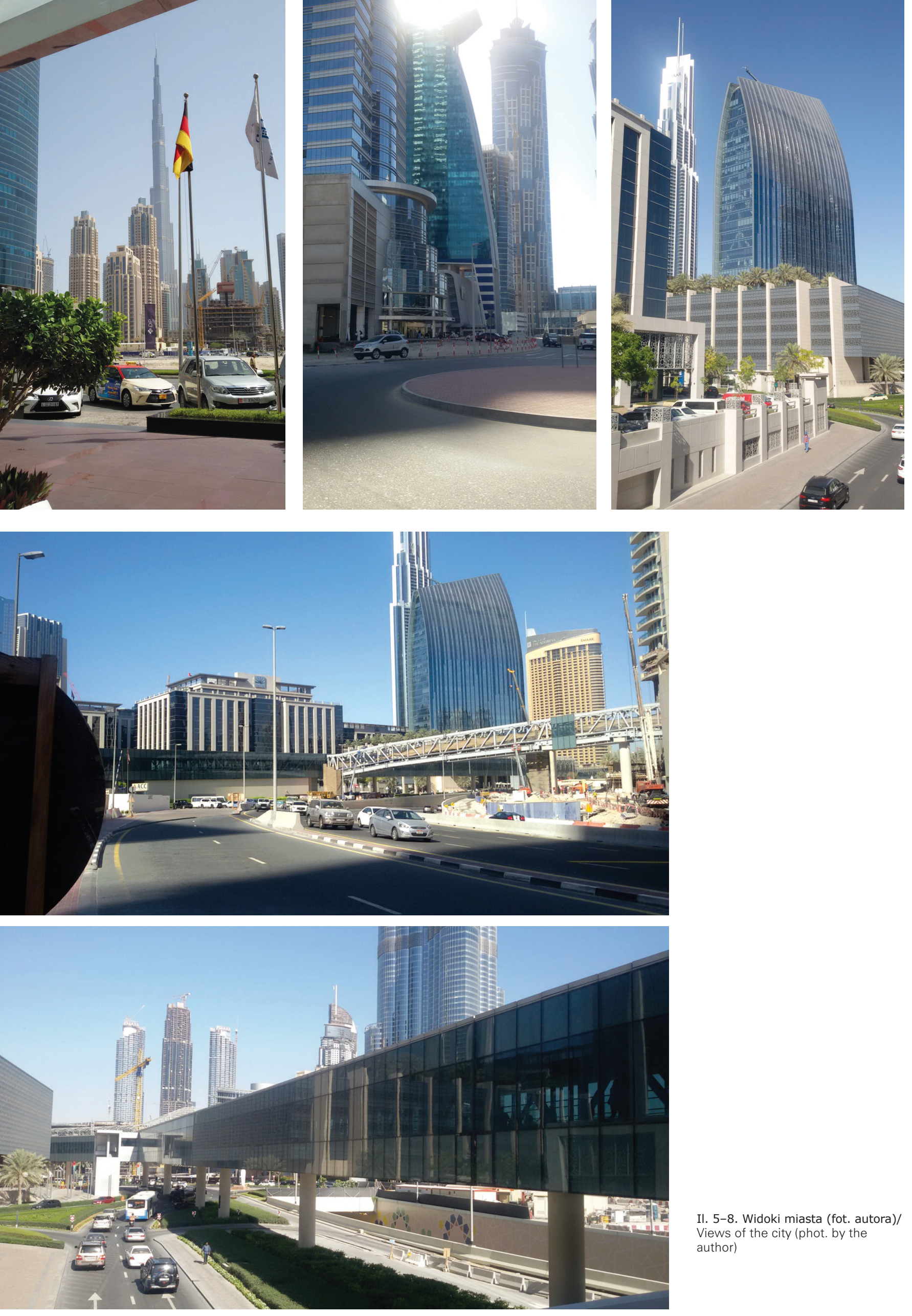

Dubaj przyjął własne unikalne podejście do inteligentnego miasta. Ta aspiracja opiera się na trzech filarach: komunikacji (czyli technologii), integracji (process) i współpracy międzyludzkiej (il. 2)

To zintegrowane podejście przyniesie owoce i pomoże osiągnąć cel, jakim jest przekształcenie się w prawdziwie globalne inteligentne miasto.

Od inteligentnych samochodów po publiczne hotspoty Wi-Fi i sprytne aplikacje lokalizacyjne - oto kilka sposobów, w jakie ten emirat przesuwa granice technologii $i$ toruje droge do inteligentnej przyszłości. ${ }^{16}$

Dubaj niekiedy może być trudnym miastem do nawigacji, ponieważ niektóre dzielnice nie mają tradycyjnego system adresowania ulic. Właśnie niedawno wprowadzono bardzo nowoczesny system - Makani Dubai17. Każdy budynek Dubaju posiada unikalny dedykowany numer, który jest wyświetlany w widocznym miejscu budynu i natural jo może być używany przez służby ratunkowe lub pojazdy dostawcze w celu znalezienia dokładnej lokalizaci adresu.

System wyposazony jest w zintegrowana aplikacje obsługi(absług nie zlokalizować dowolny adres.

Dubaj mozie poszczycić sie znakomita aplikacia dla turystó

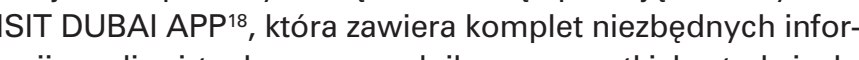
macji, Czyll wiftalny przewodnik po wszystkich atrakcjach osób które odwiedzaja emirar nátki lub długi pobyt.

\section{Podsumowanie}

Obecnie Emiraty Arabskie to światowy lider w dziedzinie zrównoważonego rozwoju.

Jednak, aby miaso bylo zowowazone, musi objac tzy

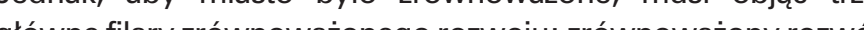
środowis zrownoważonego rozwoju: zrównoważony rozwo izarazen gosodarczy ispoleczny. Najwazh najszym celem zape zapewnienie mieszkańcom i pracownikom najwyższej jakośc zycia przy najmniej negatywnym wpływie na środowisko. $W$ ten trend znakomicie wpisuje się projekt SMART CITY. Osobiste doświadczenia nie pozostawiają złudzeń. W trakcie podróży wspaniałym bezobsługowym metrem zawieszonym $10 \mathrm{~m}$ nad poziomem terenu wzdłuż 14-pasmowej autostrady, która łączy prawie wszystkie dzielnice miasta (il. 1, 4), a jadąc można podziwiać cały Dubai i korzystać z platformy SMAR DUBAI zamawiając stolik $w$ dowolnej restauracji lub rezerwując 2-godzinne szusowanie na nartach na jedynym stoku narciarskim na pustyni, gdzie upały często przekraczają $40^{\circ} \mathrm{C}$. A to tak naprawdę dopiero ułamek możliwości...

To nie jest fantazja - patrząc z bliska na rozwój i rozmach tego wspaniałego miasta i korzystając $z$ jego udogodnień można przenieść się w prawdziwą przyszłość już teraz dotykając teraźniejszości.

To niespotykane gdzie indziej doświadczenie pozwala łączyc swiat wirtualny z rzeczywistym, gdzie smartfon wspomag człowieka ale mam nadzieję nigdy go całkiem nie zastąpi. Cały pomysł dotyczący idei SMART CITY DUBAl powstał z incjatywy Jego Wysokości Szejka Mohammeda bin Rashida Al Maktouma, który otwarcie wyraził życzenie: „.... aby DUBA stał się najszczęśliwszym miastem na ziemi' ${ }^{1 \prime \prime}$. the building and can be used by rescue services or delivery vehicles in order to find the exact location of an address.

The system comes with an integrated applicatio using GPS navigation, Garmin, which makes possible to precisely locate any address.

Dos Dubien tion including a virtual guide of all the attractions, inspirations and events that are recommended for people who are visiting the emirates either for a longer or shorter stay.

5. Conclusion

The United Arab Emirates are currently a leader in sustainable development. However, in order for a cily to be sustainable in heeds to include the three main pillars of sustainable development development The most important goal and at the same time, the mission of every sustainable city should be providing its citizens and employees with the highest quality of life with the least negative impact on the environment.

The SMART CITY excellently fits into this trend. Personal experiences leave one without any illusions. Travelling using a magnificent uncrewed metro rail suspended $10 \mathrm{~m}$ above ground leve along a 14-lane freeway that connects nearly every district of the city (iil. 1, ill. 4) One can see the entirety of Dubai and, using the SMART DUBAl platform, moke a reserv 2 ho hor a table at any restaurant the desert, where the heat often exceeds $40^{\circ} \mathrm{C}$. And this is just a fraction of the possibilities.

This is not a fantasy - when looking closely at the development and flair of this wonderful city and using its conveniences we can be transported into a true future right now through touching the present.

This unique experience that can be found nowhere else makes it possible to combine the virtual an the real world, where a smartphone aids a person, but will never - at least that is my hope - replace hem completely.

TITY entire idea regarding the concept of SMART 列 who openly expressed the wish to ". make DUBA the happiest city on Earth"19.

ENDNOTES

T. Zipser, Miasto - maszyna czy tkanka? Technical Tran-

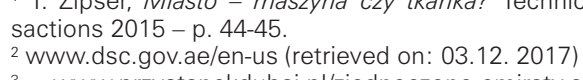
Www.pryystanekdubaj.pl/ziednoczone-emiraty-arabskie-
od-pustyni-bogactwa (retrieved on: 28.11. 2017)

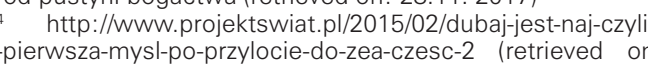
20.10.2017) 5 WwW.expo2020dubai.ae/en//expo-2020-dubai (retrieved
$03.10 .2017)$
6 http://www.smartdubaiae (retrieved on 03.10.2017) 4aecabinet.ae/en/ddetails/l/cabinete-members/his-highness-
-sheikh-mohammed-bin-rashid-al-maktoum (retrieved on -sheikh-moh
20.10.2017) 


\section{PRZYPISY}

1 T. Zipser, Miasto - maszyna czy tkanka? Technical Transactions 2015 - s. 44-45 ${ }^{2}$ www.dsc.gov.ae/en-us (dostep: 03.12. 2017)

www.przystanekdubaj.pl/zjednoczone-emiraty-arabskie-od-pustyni-bogactwa (dostęp: 28.11. 2017)

4 http://www.projektswiat.pl/2015/02/dubaj-jest-naj-czyli-pierwsza-mysl-po-przylocie-do-zea-czesc-2 (dostepp 20.10.2017)

${ }^{5}$ www.expo2020dubai.ae/en/expo-2020-dubai (dostęp 03.10.2017)

${ }^{6} \mathrm{http}: / /$ www.smartdubai.ae (dostęp 03.10.2017)

7 uaecabinet.ae/en/details/cabinet-members/his-highness-sheikh-mohammed-bin-rashid-al-maktoum (dostep 20.10.2017)

8 http://www.pacificcontrols.net/news-media/DCD_launches_personal_dashboard for residents. (dostęp 20.10.2017)

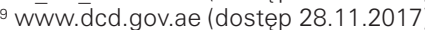

10 Catalin-Constantin Usurelu and Florin Pop - My City Dashboard: Real-time Data Processing Platform for Smart City. Journal of Telecommunications and Information Technology $1 / 2017$

11 http://www.smartdubai.ae/foundation vision.php (dostep 23.11.2017)

$12 \mathrm{http}: / / w w w . s m a r t s k y s c r a p e r s . c o m / n e w s-d e t a i l: 4 e 8 f 3 b e 0-d 831-e d 28-8 \mathrm{~d} 3 \mathrm{e}-$

597ed05fcd60. (dostęp 18.11.2017)

3 http://www.smartskyscrapers.com/news-detail:4e8f3be0-d831-ed28-8d3e597ed05fcd60. (dostep 23.11.2017)

${ }^{14}$ www.dsoa.ae/en/about-dubai-silicon-oasis (dostęp 17.11.2017)

$15 \mathrm{http}: / /$ www.dsocity.ae/about-community (dostęp 17.11.2017)

${ }^{16}$ www.visitdubai.com/en/articles/smart-city (dostęp 23.11.2017)

17 /wwW.visitdubai.com/en/articles/smart-city (dostep 23.11.2017)

18 wWw.visitdubai.com/en/travel-planning/travel-tools/get-the-app (dostęp 23.11.2017)

${ }^{19} \mathrm{http}: / /$ www.smartdubai.ae/foundation vision.php dostęp 28.11.2017.

\section{LITERATURA}

[1] Zipser T., Miasto - maszyna czy tkanka? Technical Transactions 2015

[2] Catalin-Constantin Usurelu and Florin Pop - My City Dashboard: Real-time Data Processing Platform for Smart City. Journal of Telecommunications and Information Technology $1 / 2017$

[3] www.smartskyscrapers.com

[4] www.smartdubai.ae

[5] www.dsoa.ae/en/

6] assets.kpmg.com/content/dam/kpmg

[7] www.visitdubai.com/en/articles/smart-city

[8] www.national-geographic.pl/traveler/zjednoczone-emiraty-arabskie-to-nie-tylko-dubaj-zobacz-niezwykle-miasta-przyszlosci
8 http://www.pacificcontrols.net/news-media/DCD launches personal dashboard for residents. (retrieve $\bar{d}$ on 20.10.2017)

${ }^{9}$ www.dcd.gov.ae (retrieved on 28.11.2017)

10 Catalin-Constantin Usurelu and Florin Pop - My City Dashboard: Real-time Data Processing Platform for Smart City. Journal of Telecommunications and Information Technology $1 / 2017$

11 http://www.smartdubai.ae/foundation vision.php (retrieved on 23.11.2017)

12 http://www.smartskyscrapers.com/news-detail:4e8f3be0d831-ed28-8d3e-597ed05fcd60. (retrieved on 18.11.2017)

13 http://www.smartskyscrapers.com/news-detail:4e8f3be0d831-ed28-8d3e-597ed05fcd60. (retrieved on 23.11.2017) 14 www.dsoa.ae/en/about-dubai-silicon-oasis (retrieved on 17.11.2017)

15 http://www.dsocity.ae/about-community (retrieved on 17.11.2017

16 www.visitdubai.com/en/articles/smart-city (retrieved on 23.11.2017)

17 /www.visitdubai.com/en/articles/smart-city (retrieved on 23.11.2017)

${ }^{18}$ www.visitdubai.com/en/travel-planning/travel-tools/get-the-app (retrieved on 23.11.2017)

19 http://www.smartdubai.ae/foundation vision.php retrieved on 28.11.2017.

\section{BIBLIOGRAPHY}

[1] Zipser T., Miasto - maszyna czy tkanka? Technical Transactions 2015

[2] Catalin-Constantin Usurelu and Florin Pop - My City Dashboard: Real-time Data Processing Platform for Smart City. Journal of Telecommunications and Information Technology $1 / 2017$

[3] wWW.smartskyscrapers.com

[4] wWW.smartdubai.ae

[5] www.dsoa.ae/en/

[6] assets.kpmg.com/content/dam/kpmg

[7] www.visitdubai.com/en/articles/smart-city

[8] www.national-geographic.pl/traveler/zjednoczone-emiraty-arabskie-to-nie-tylko-dubaj-zobacz-niezwykle-miasta-przyszlosci 